\title{
Korean Economy: From Protectionism to Liberalism
}

\author{
Tan Soo Kee
}

\begin{abstract}
This paper examines the transformation of the Korean development model since the 1960s. The statedirected capitalism that characterized the close liaison between government and business successfully transformed Korea into an industrial powerhouse in the 1970s. Under the strong leadership of Park Chung Hee, the Korean government picked industrial winners and promoted them with cheap capital and protection to boost industrial productions and exports. This guided capitalism was very successful, but the Korean government began to abandon the ideology and moved toward liberalism gradually since 1980s. Under the Chun Doo Hwan's administration, the active role of the state in the economy was reduced, allowing more freedom in the market. Then the government began to emphasize liberalizing the economy for foreign goods, capital, and free operation of the market by minimizing government control. After the 1997 financial crisis, promoting foreign direct investment into the country and signing FTAs became important growth strategies for the Korean economy. It is believed that the neoliberalism will continue to override the nation's economic direction for welfare of the country.
\end{abstract}

Keywords: Korean economy, protectionism, liberalism

\section{Introduction}

In the highly competitive globalized age, openness to the world is becoming more important. Under an open system, integration of national markets in the global economy is less restricted by protectionist policies. As suggested by many economists such as Adam Smith, resources will flow to the most efficient allocations under a free and open market system, which will help to increase the welfare of a country. Adam Smith's ideas for promoting the free market system are the basis of economic liberalism, which has flourished in the Western world since the 18th century. A free economic system allows the free flow of capital, goods, and services, but it comes with the problem of fluctuation and instability at the national level. Thus, policy regulations play a significant role in balancing fast growth and stability, as claimed by Keynesian economics. Although economic liberalism can also be supportive of government regulation to a certain degree, it tends to oppose government intervention in the free market when it inhibits free trade and open competition. Today, economic liberalism is generally considered to be opposed to noncapitalist economics orders, such as socialism and planned economies. ${ }^{1}$

The ideas of openness and liberalism in the economy continue to spread throughout the world through free trade agreements and the formation of free trade zones. Deregulation, privatization, and withdrawal of the state from many areas of social provision have become common. ${ }^{2}$ Even contemporary China, which has had incredible economic growth rates for the past three decades also appears to be headed in this direction. Attributed to openness, the Chinese economy has experienced tremendous change since Deng Xiao Ping advocated the open market system in 1978. The success of the Chinese economic reformation has confirmed the theory of liberalism. Harvey David stated that "the advocates of the liberal ideas occupy positions of considerable influence in education, in the media, in corporate boardrooms and financial

\footnotetext{
${ }^{1}$ Brown Wendy, Edgework: Critical Essays on Knowledge and Politics, Princeton University Press, 2005, p.39.

${ }^{2}$ Harvey David, A Brief History of Neoliberalism, Oxford University Press, 2005.
} 
institutions, in key state institutions (treasury departments, the central banks), and also in international institutions such as the International Monetary Fund (IMF), the World Bank and the World Trade Organization (WTO) that regulate global finance and trade". ${ }^{3}$ Liberalism has become hegemonic as a mode of discourse for modernizing a nation. ${ }^{4}$

Moon Hwy Chang's OUI model demonstrated that openness is significant in strengthening a nation's competitiveness. ${ }^{5}$ Aggressiveness and attractiveness are the two sub-variables under this dimension that can be used to characterize two different ways of opening a country. ${ }^{6}$ A country demonstrates attractiveness when it creates an environment that encourages the inflow of foreigners, foreign goods, and foreign investments (inbound orientation). On the other hand, a country is aggressive when it prefers to go into the world through emigration, exports, and foreign investments (outbound orientation). People with low openness act according to their emotions and are considered nationalistic and protective. ${ }^{7}$ Korea is more aggressive at pursuing global investment and business. ${ }^{8}$

Based on Tan Soo Kee's quantitative analysis findings, the openness value level affects a country's FDI inflow and trade performance. ${ }^{9}$ The study shows that the cultural openness level has a positive relationship with trade and foreign investment levels. All the richest economies in the world, such as Sweden, Switzerland, the UK, Norway, Canada, Australia, Finland, and the United States are top scorers in terms of openness as well as FDI inflow, which indicates that northwestern Europe is the most open cultural bloc. ${ }^{10}$ This is not surprising as liberalist philosophy has flourished in the region since the late 17 th century. The ideas of liberalism, which are strongly associated with openness, have continued to exert significant influence on the culture, politics, and government of the Western world for few hundred years. In other parts of the world, particularly the Asian region, the openness level is relatively much lower. Northeast Asian countries such as China, Korea, and Japan are not only less open culturally but also in terms of trade openness and FDI inflow. The significant positive relationship between openness values and FDI net inflows may reflect the influence of openness values on their trade and FDI inflows.

\section{The Case of South Korea}

Korea, as a homogenous culture, has had a long history of isolation from the world, particularly during the Choson period, when the government purposely isolated the country from the world and international trade was discouraged. Presently, Korea is still ranked at the bottom of the openness index list as well as on trade and FDI openness index lists. FDI net inflow per capita and the trade openness index in Korea remain low compared to other countries (see Figures 1 and 2). In cultural terms, Korea also shows low openness levels based on Inglehart's World Value Survey

\footnotetext{
${ }^{3}$ Harvey David, A Brief History of Neoliberalism.

${ }^{4}$ Harvey David, A Brief History of Neoliberalism.

${ }^{5}$ Moon Hwy Chang, "Cooperation Among Japan, Korea and China Through Sharing Business and Cultural Advantages," The Review of Business History, Vol 19.No.3, December, 2004 .

${ }^{6}$ Moon Hwy Chang and Choi Eun Kyong, Cultural Impact on National Competitiveness, Journal of International and Area Studies, Vol.8, no.2, 2001.

${ }^{7}$ Moon Hwy Chang and Choi Eun Kyong, Cultural Impact on National Competitiveness.

${ }^{8}$ Moon Hwy Chang and Choi Eun Kyong, Cultural Impact on National Competitiveness.

${ }^{9}$ Tan Soo Kee,'The Relationship Between Cultural Values and National Competitiveness: General Pattern and Specific Country Studies of South Korea and Malaysia,' Doctoral dissertation, Seoul National University, 2014.

${ }^{10}$ Tan Soo Kee,'The Relationship Between Cultural Values and National Competitiveness'.
} 
$(2005,2006)$ results. For example, 31.9 percent of Koreans answered that they would not like to have people who speak different languages as neighbors. ${ }^{11}$ This indicates that in general, Koreans feel more uncomfortable when meeting people who are different from themselves culturally. This may due to the homogenous nature of Korea, which speaks one language and shares one culture.

\section{Liberalization of Inward Foreign Investment}

Korea, as an economy which promoted export growth since the 1960s, had high levels of restriction on foreign investments in the early development stage, particularly during Park Chung Hee's administration. In 1961, there was only one FDI project permitted by the government, which increased to 50 projects in 1970 and 55 in $1982 .{ }^{12}$ From 1961 to 1984 , the number of yearly FDI approval projects was typically less than one hundred. Protectionist policy was dominant in the nation state development policy. Korean local firms' growth was given top priority, with strict import policies and FDI restrictions. Foreign investment climate was slightly improved from the middle of 1980s following the country leadership change. By 1980, foundation for the Heavy and Chemical Industry was created and the government shifted focus to improve national competitiveness through the creation of open economy. Chung Doo Hwan's administration, a young government which elected politicians mostly less than 50 years old, started economic liberalization measures from early 1980s. Some Korean policymakers became more vocal in support of the desirability of introducing more competition into domestic markets, as a way to gain the benefits of greater openness predicted by economic theory. Protectionist policy was reduced both to import restrictions as well as in FDI policy. In 1985, the "positive list" (allowing FDI in specific sectors) was replaced by "negative list" (allowing FDI in all sector except where specifically prohibited), which led to substantial increased number of industries open to FDI. Nonetheless, protectionism remained strong throughout the 1980s.

Korean local firms continued to resist FDI competition and put pressure on the government to keep foreign investors out of Korea. ${ }^{13}$ Domestic companies were not equipped for international competition as they had been receiving government's support and protection since 1960s, resulting in less focus on effectiveness. However, after Kim Young Sam took over the administration in 1993, he continues to adopt significant measure toward economic liberalization. One of the measures is to promote foreign investments in Korea. In 1994 Kim Young Sam stated that, "Our goal is to make Korea one of the best places in the world for foreigners to do business, and we believe it is very important to make Korea secure and attractive for foreign investors." 14

Since then, the Korean government has reduced barriers to foreign participation in the Korean market and removed obstacles to investment and joint ventures. For instance, one-stop centers for foreign investors were opened, and the decision on an application for building a plant is made within forty-five day. Foreign companies that invest in Korea with strategic cutting-edge technology will have their corporate tax waived until years after they have earned their first profits. ${ }^{15}$ Stock market and bond market also opened to foreign investors. Consequently, FDI in

\footnotetext{
${ }^{11}$ World Value Survey online database. 2010, accessed May 16 2010, http://www.worldvaluessurvey.org/

${ }^{12}$ Stoever William A., "Attempting to Resolve the Attraction-Aversion Dilemma: A Study of FDI Policy in the Republic of Korea, Transnational Corporation, Vol.2, no.1, April 2002, UNCTAD, p.53.

${ }^{13}$ Stoever William A., "Attempting to Resolve the Attraction-Aversion Dilemma".

${ }^{14}$ Kim Eun Young, A Cross-Cultural Reference of Business Practice in a New Korea. London: Quorum Books, 1996, p.18.

${ }^{15}$ Kim Eun Young, A Cross-Cultural Reference of Business Practice in a New Korea, p.18
} 
Korea rose substantially, as shown in figure 1 below. Share of FDI inflow to GDP rose continuously since 1993 to 1997 under the liberalization program.

Figure 1 Share of FDI inflow to GDP, Korea

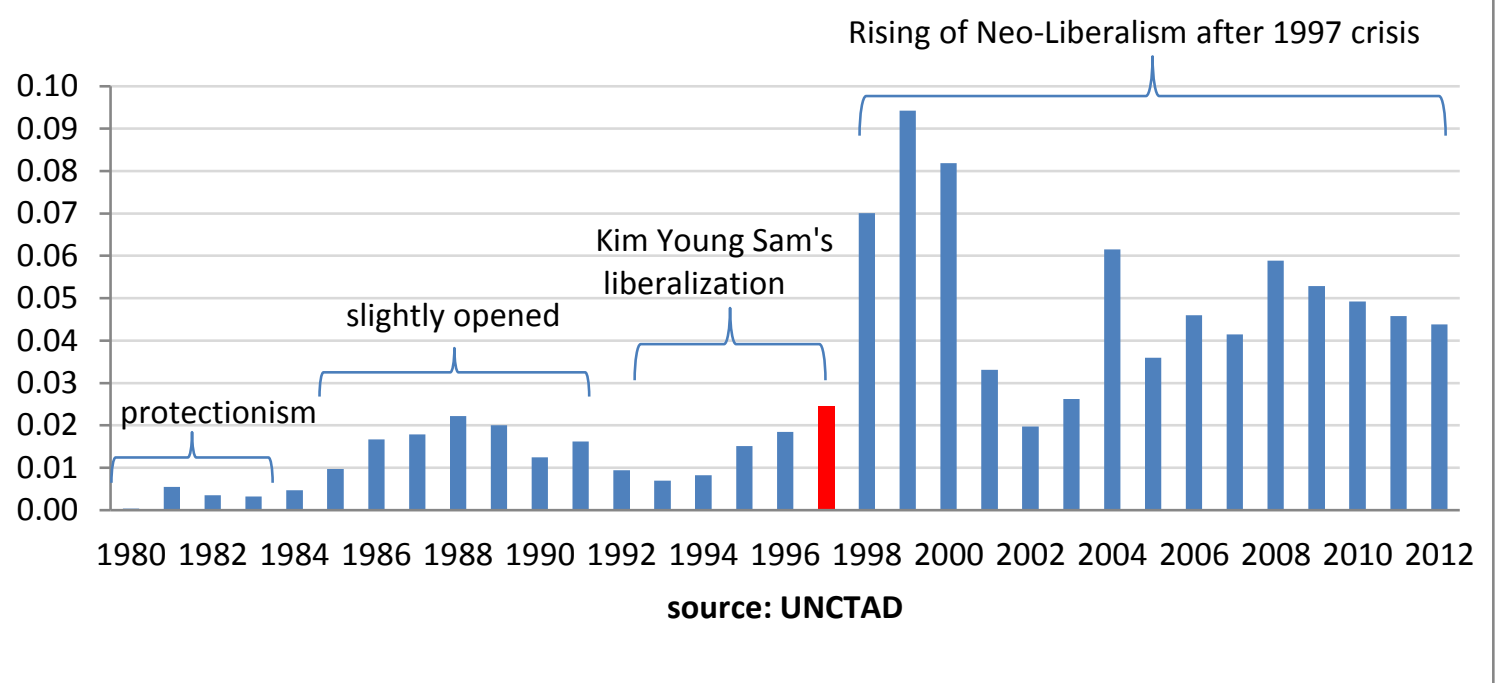

Figure constructed by author based on the source of UNCTAD.

Under Kim Young Sam's administration, liberalization of Korean economy was sped up under the segyehwa (globalization) policy. According to Kim, building a "New Korea" is important to cure the so-called "Korean disease" inherited from authoritarianism of the past. He believed that Korea need new vision in the twenty-first century by clamming that "entails rationalizing all aspects of life" and "reforms in every area". ${ }^{16}$ Kim Young Sam stated; "Globalization is the shortcut which will lead us to building a first-class country in the $21 \mathrm{st}$ century...It is aimed at realizing globalization in all sectors-politics, foreign affairs, economy, society, education and culture and sports...it is necessary to enhance our viewpoints, way of thinking, system and practices to the world class level". ${ }^{17}$

As a consequence, the Korean financial sector and market was greatly liberalized. Korea's traditional development model, which stressed on state's role, was dismantled. Although the aggressive liberalization reforms caused serious financial crisis in 1997, neoliberalism continued to override the nation economic direction under the new structural adjustment. Under the IMF rescue package, neoliberalism gained dominance with greater trade liberalization and removal of all barriers to the cross-border flows of capital, goods and services, with the extended role of the market and the re-oriented role of state. ${ }^{18}$ Free market and limited state intervention was the basic principle of the reforms. The key reforms required by the IMF included the need to "break the close links between government and business" that defined the Korean development model,

\footnotetext{
${ }^{16}$ Lim Hyun Chin and Jang Chin Ho, Between Neoliberalism and Democracy: The Transformation of the Developmental State in South Korea. Development and Society, Vol. 35, no.1, June, pp. 1-28.

${ }^{17}$ Korea Times, 7 January 2005 in Lim Hyun Chin and Jang Chin Ho, Between Neoliberalism and Democracy: the Transformation of the Developmental State in South Korea, pp.1-28

${ }^{18}$ Lim Hyun Chin and Jang Chin Ho, Between Neoliberalism and Democracy: the Transformation of the Developmental State in South Korea, pp.1-28.
} 
"ensure the integration of the national economy with international financial markets," increase the "potential for foreign participation in domestic financial systems," and "remove impediments to growth such as monopolies and trade barriers". 19

Under the Kim Dae Jung's administration, foreign investment was promoted greatly not only to rescue some troubled Korean firms but also to help Korean economy to grow. As a consequent, the number of foreign-invested companies in Korea has increased substantially since 1998. As indicated in the Figure 3, FDI inflow to Korea rose exponentially particularly from 1998 to 2000. This was mainly due to purchases of troubled Korean companies by foreign companies after the crisis. The overall contribution of FDI to Korean GDP has been much higher compared to pre-1997 crisis. To promote foreign investments in Korea, the Korean government pursed a series of promotion programs. Passage of the Foreign Investment Promotion Act in 1998 greatly facilitated these efforts. The Act opened up 99.8 percent of Korea's industries to foreign investment and provided significant protection for investors' interest. Under the Act, foreign investors receive incentives including tax breaks, cash grants and affordable land. ${ }^{20}$ As a result, the great openness to foreign investors made big achievement to Korea. Attractions of Korea to foreign investors included its R\&D facilities, logistics centers and pool of human resources in science and engineering. The Korean government aims to make Korea as the North East Asian financial hub.

Following the removal of restrictions on foreign ownerships of South Korean stocks, foreign investors now own about 60 percent of the shares in some of Korea's top companies and nearly 33 percent of stock listed on Korea's main stock exchange. ${ }^{21}$ South Korean equity markets have become more integrated with international market. The linkages between NASDAQ and KOSDAQ, and the KOSPI are particularly noticeable. However, it made South Korea more vulnerable to downturns in the US market than it was times in the past. ${ }^{22}$

Nonetheless, despite the friendly FDI policy and substantial increase of FDI in Korea, in recent years FDI has fallen as shown in the figure three. Share of FDI inflow to nation GDP dropped consistently from year 2008-2012. Based on the meeting of Korea's former Prime Minister Kim Hwang-sik with foreign investors, it was found that Korea suffered an image problem for its hostile attitudes toward foreign investors. ${ }^{23}$ International investors were concerned when about 10 financial regulators are being investigated or jailed for taking bribes. The problem of Lone Star from KEB also confused many foreign investors about the sincerity of Korean government in ensuring free capital movement. ${ }^{24}$ Internal pressure from local firms to against foreign competition in local market also has been continued. ${ }^{25}$ David Eldon, the chairman of the

\footnotetext{
${ }^{19}$ IMF 1999 cited in Crotty James and Lee Kang Kook, Was the IMF's Imposition of Economic Regime Change in Korea Justified? A Critique of the IMF's Economic and Political Role Before and After the Crisis. Political

Economy Research Institute, Working paper series no.77, University of Massachusetts Amherst, 2004. Accessed Jan 10 2016. http://scholarworks.umass.edu/cgi/viewcontent.cgi?article=1063\&context=peri_workingpapers

${ }^{20}$ MOFA, Korea.

${ }^{21}$ IBP, Korea (South) Investment and Business Guide: Strategic and Practical Information. Washington: International Business Publications, 2013.

${ }^{22}$ Marcus, Noland, "Economic Reform in South Korea: An Unfinished Legacy", paper presented at the Conference of "Korea as the $21^{\text {st }}$ Century Power", University of Cambridge, 2002, accessed September 2016, https://piie.com/commentary/speeches-papers/economic-reform-south-korea-unfinished-legacy

${ }^{23}$ Hostile Investment Policy. Korea Times, June 21, 2011, accessed April 10, 2013, accessed April 102013. http://koreatimes.co.kr/www/news/opinon/2011/06/137 89327.html

${ }^{24}$ Ibid.

25 Stoever William A., "Attempting to Resolve the Attraction-Aversion Dilemma: A Study of FDI Policy in the Republic of Korea, p.53.
} 
Dubai International Financial Center Authority, who also serves as a special advisor to the Presidential Committee on national competitiveness, commented that Korea should take a friendlier attitude towards foreigners. He mentioned that, "the Korean government can do a number of things to rules and regulations that will assist in creating an attractive investment climate, but the key must be how willing the Korean people are to accept foreigners and their investments. In this regard there seem to be some doubt...other economies were moving much quicker than Korea in creating financial centers, and Shanghai is a good example, and other Chinese cities are also moving forward quickly". ${ }^{26}$ The investment climate's report of U.S Bureau of Economic and Business Affairs in 2013 mentions that unclear and opaque regulatory decision-making has remained a significant concern for foreign investors in Korea. According to the report, investors are also concerned about significant interest groups that pressure the government to protect the Korean local market from what is perceived as foreign domination. In addition, the volatility in labor-management relations is also an issue that may hamper FDI. The bureaucratic process is one of the most difficult obstacles to attract FDI in Korea. ${ }^{27}$ Stoever William in his study find that one major problem was to get lower-level bureaucrats to implement reforms promulgated by top-level ministers, inefficiencies of lower-level bureaucrats in handling FDI application created many delays. ${ }^{28}$ Certainly the Korean government needs to pay more efforts to create business friendly environment to foreign investors.

The lower openness of Korea to the world is reflected in FDI policy. As reported in the report of Economic Freedom of the World in 2016, restriction of foreign ownership and investment in Korea is high. Korea's rating in term of foreign ownership restriction in 1995 was only 4.66, but increased to 7.16 in 2000 due to a substantial change of government FDI policy after 1997 crisis. As an economy which is currently facing the high unemployment rates among youth, attracting more foreign investments into the country would be helpful to create more jobs opportunities.

\footnotetext{
${ }^{26}$ A More Open Economy Key to Korea’s Future, Korea Times, May 29, 2008, accessed May 252010 http://www.koreatimes.co.kr/www/news/nation/2009/11/242_25027.html

${ }^{27}$ Stoever William A., "Attempting to Resolve the Attraction-Aversion Dilemma: A Study of FDI Policy in the Republic of Korea, p.53.

${ }^{28}$ Stoever William A., "Attempting to Resolve the Attraction-Aversion Dilemma: A Study of FDI Policy in the Republic of Korea, p.53.
} 


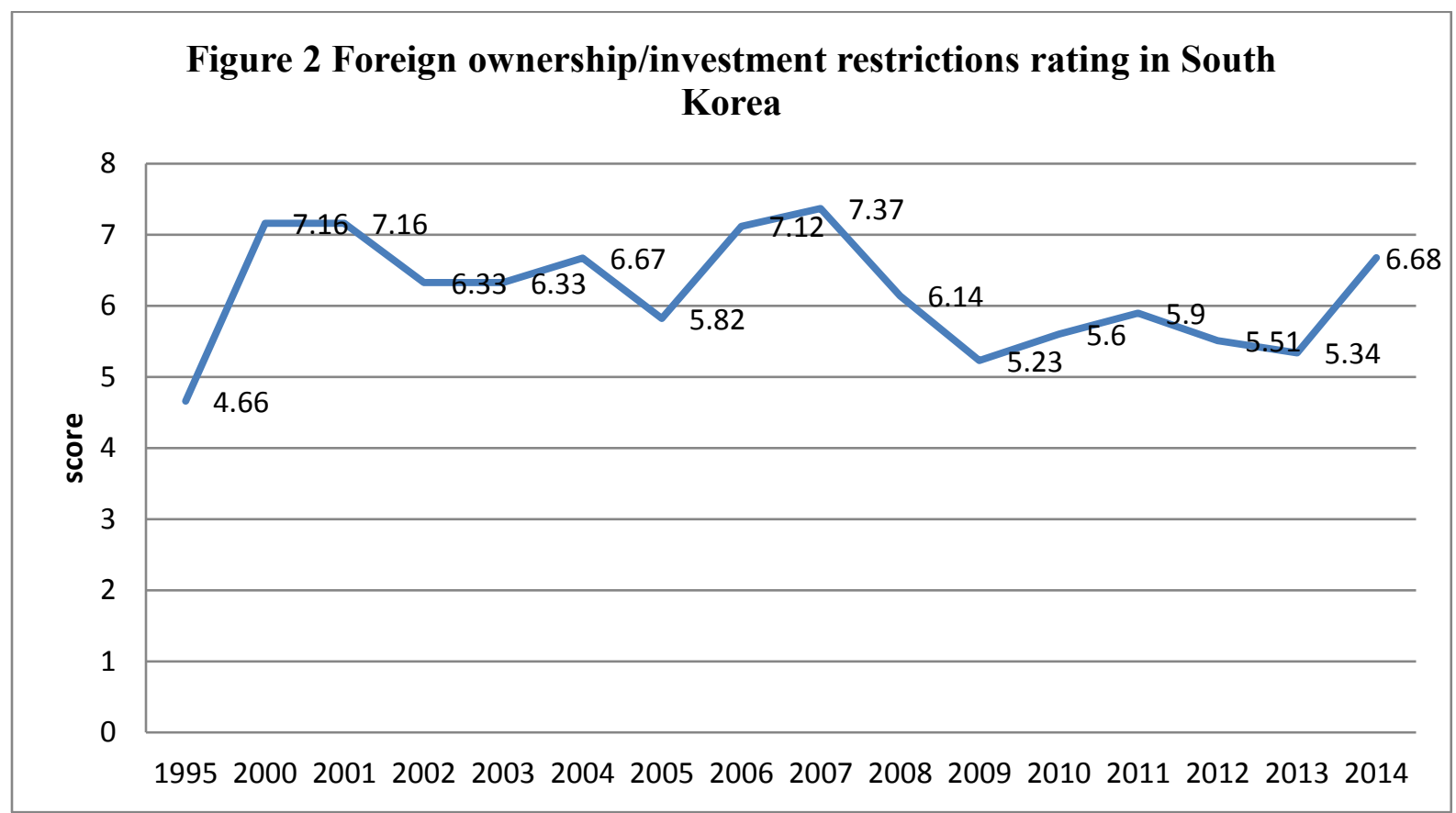

Source: Figure constructed based on the data from the annual report Economic Freedom of the World (2016)

\section{Korea's Trade Liberalization}

Korea's trade openness has a similar development path to FDI openness. Historically, Korea closed its door to international trade during the Choson dynasty. The national history of international exposure and trade is rather short. ${ }^{29}$ Although Korea began industrialization after the Korean War, the Korean government imposed high restrictions on import markets from the 1960s to the 1970s. During Park Chung Hee's administration, the trade regime was characterized as outward looking on the export side and restrictive on the import side. The links between the government and private sectors were very close. To facilitate the growth of local infant industries particular the Korean manufacturers, the Korean government imposed high tariff barriers as well as nontariff barriers to import products. The import liberalization plan was initiated in late 1970s, when the balance of payment improved substantially. ${ }^{30}$ To help local Korean firms grow, all imports were processed through a strict and complex sequence involving the issuance of import licenses, quantity controls, settlement methods, deposits in advance, and customs clearance. ${ }^{31}$ The unrestricted import items were only limited to intermediate goods for export that could not be manufactured in Korea. Because Korean firms rely heavily on foreign raw materials and machinery, the government allowed exporting firms to freely import (import licensing) raw materials, capital goods, and parts required for the production of exports, up to the amount of export earnings ${ }^{32}$ As a result, crude materials, chemical products, machinery, and equipment were the major import items of Korea compared to consumer goods.

${ }^{29}$ Il Sa Kong, Korea in the World Economy. Washington: Institute for International Economics, 1993, p.20.

${ }^{30}$ Il Sa Kong, Korea in the World Economy, p.87.

31 Yoo Hak Sang, 1985, cited in Seo Ick Jin, 'Industrialization in South Korea: Accumulation and Regulation,' In Lee Byeong Cheon eds, Developmental Dictatorship and the Park Chung Hee Era: The Shaping of Modernity in the Republic of Korea. New Jersey: Homa and Sekey Books, 2003, p.68.

32 Byung Nak Song, The Rise of the Korean Economy. Hong Kong: Oxford University Press, 1997, p.101. 
To protect local infant industries, products that were able to be produced domestically were put on the list of import restriction. ${ }^{33}$ Following the changes in government in 1981, restrictions on import items were greatly reduced (see Table 1). The decision to liberalize was based on the belief that to increase national competitiveness, import liberalization was inevitable. Under the import liberalization's policy, it was argued that exposure to international competition would force Korean firms to reduce inefficiency and become more innovative. ${ }^{34}$ To survive in a highly competitive business world, liberalization would help Korean firms accelerate their international competitiveness and technological development. The following Table 1 shows the import liberalization progress from 1977 to 1991 . Only 691 items had automatic approval in 1977 (53\% of all items), but that increased to 9,991 items in 1991 (97 percent of all items).

Table 1 Korea's Import Liberalization, 1977-1991

\begin{tabular}{|l|l|l|}
\hline Year & All items & Items with automatic approval \\
\hline 1977 & 1312 & 691 \\
\hline 1978 & 1097 & 712 \\
\hline 1979 & 1010 & 683 \\
\hline 1980 & 1020 & 693 \\
\hline 1981 & 7645 & 5576 \\
\hline 1982 & 7560 & 5791 \\
\hline 1983 & 7560 & 6078 \\
\hline 1984 & 7915 & 6712 \\
\hline 1985 & 7915 & 6945 \\
\hline 1986 & 7915 & 7245 \\
\hline 1987 & 7911 & 7408 \\
\hline 1988 & 10241 & 9694 \\
\hline 1989 & 10241 & 9776 \\
\hline 1990 & 10274 & 9898 \\
\hline 1991 & 10274 & 9991 \\
\hline
\end{tabular}

Source: Il Sakong, $1993 .^{35}$

As suggested in Table 1, the import licensing liberalization rate was to be raised to 95 percent in total by 1988 . Primary products, food, and beverages were largely protected in the $1970 \mathrm{~s}$ and slowly liberalized after 1981. Agricultural products were exempted from the import licensing liberalization program to protect the interests of local Korean farmers.

\footnotetext{
${ }^{33}$ Seo Ick Jin, 'Industrialization in South Korea: Accumulation and Regulation,' p.68.

${ }^{34}$ Young Soo Gil, Import Liberalization and Industrial Adjustment in Korea. Korea Development Institute: Working Paper 8613, 1986, p.14, accessed April 19 2016,

http://www.kdi.re.kr/kdi_eng/publication/publication_view.jsp?pub_no=769\&pg=6\&tema=D1\&pp=10

${ }^{35} \mathrm{Il}$ Sa Kong, Korea in the World Economy, p. 88
} 
Table 2 Import Licensing Liberalization Program in Korea, 1981-1988 (as of 1 July annually)

\begin{tabular}{|l|l|l|l|l|l|l|l|l|l|}
\hline & \multirow{2}{*}{$\begin{array}{l}\text { Number } \\
\text { of items }\end{array}$} & \multicolumn{2}{|c|}{$\begin{array}{l}\text { Proportion of items subject to automatic import approval under } \\
\text { the regular trade notice (\%) }\end{array}$} \\
\cline { 3 - 9 } & 1981 & 1982 & 1983 & 1984 & 1985 & 1986 & 1987 & 1988 \\
\hline $\begin{array}{l}\text { Primary } \\
\text { products, food, } \\
\text { and beverages }\end{array}$ & 1386 & 68.5 & 70.6 & 73.2 & 75.8 & 78.2 & 79.7 & 80.1 & 80.5 \\
\cline { 1 - 9 } $\begin{array}{l}\text { Chemical } \\
\text { products, paper, } \\
\text { and ceramics }\end{array}$ & 2182 & 93.4 & 94.0 & 94.4 & 95.0 & 95.6 & 97.7 & 99.1 & 99.6 \\
\hline $\begin{array}{l}\text { Steel and metal } \\
\text { products }\end{array}$ & 802 & 88.9 & 89.7 & 90.9 & 92.8 & 95.6 & 99.4 & 100 & 100 \\
\hline $\begin{array}{l}\text { General } \\
\text { machinery }\end{array}$ & 1414 & 64.2 & 65.5 & 68.7 & 78.0 & 83.0 & 89.4 & 93.3 & 100 \\
\hline $\begin{array}{l}\text { Electrical and } \\
\text { electronic } \\
\text { machinery }\end{array}$ & 495 & 40.9 & 46.1 & 53.6 & 62.4 & 73.0 & 87.0 & 95.5 & 100 \\
\hline $\begin{array}{l}\text { Textile } \\
\text { products, } \\
\text { including } \\
\text { leather garments }\end{array}$ & 1089 & 65.4 & 68.4 & 80.4 & 90.3 & 93.1 & 95.1 & 96.9 & 97.8 \\
\hline Others & 547 & 71.2 & 75.7 & 81.2 & 82.1 & 82.8 & 85.7 & 88.2 & 88.2 \\
\hline Total & 7915 & 74.7 & 76.6 & 80.4 & 84.8 & 87.7 & 91.6 & 93.6 & 95.4 \\
\hline
\end{tabular}

Source: Ministry of Trade and Industry, $1986^{36}$

Under the liberalization program, Korea's openness toward international trade has continued to increase steadily. As shown in the Table 2, Korea's trade openness was pretty low during 1980s but improved substantially since 1990. For instance, by 1983, of some 10,000 product classes, 19.6 percent contained import restrictions. ${ }^{37}$ By 1989, the fraction had dropped to only 5.3 percent, and most of these were primary commodities. Only 46 industrial products continued to have import licensing or prohibition. ${ }^{38}$ With the new leadership and dominance of liberalists in elite groups, Korean leaders believed that Korea has no choice except open up to foreign competition to enhance the local industrialists' competition. With the help of a selectively liberal import strategy, Korea has been able to develop a highly competitive manufacturing sector that offers its own brand-name manufactures of increasing sophistication. The liberalization of Korea has sped up since the administration of Kim Young Sam. On November 17, 1994, Kim Young Sam announced his globalization (segyehwa) policy with the purpose of making the country an advanced nation. Under the liberalization policy, the Kim Young Sam government eliminated many of the restrictions on capital flow, enabling Korean banks and big business to borrow from

\footnotetext{
36 Young Soo Gil, Import Liberalization and Industrial Adjustment in Korea. p.27, accessed April 192016 , http://www.kdi.re.kr/kdi_eng/publication/publication_view.jsp?pub_no=769\&pg=6\&tema=D1\&pp=10

37 Dornbusch Rudiger, "The Case of Trade Liberalization in Developing Countries". The Journal of Economic Perspectives, Vol.6, no.1, Winter 1992, pp. 69-85.

${ }^{38}$ Dornbusch Rudiger, "The Case of Trade Liberalization in Developing Countries".
} 
abroad..$^{39}$ Nonetheless, Kim Young Sam's liberalization program was criticized as poorly designed and mismanaged and failed to establish a regulatory system to govern and monitor capital flow and investments, which contributed to over borrowing using foreign loans by Korean firms and created the debt crisis in $1997 .{ }^{40}$

After suffering from 1997's financial crisis, the Korean government continued to liberalize Korea in various ways. Even though Kim Young Sam's liberalization program was blamed for causing the financial crisis in Korea, President Kim Dae Jung continued the liberalization policy with a new set of regulations. To survive in the brave new world of unbounded global competition, the Korean government thinks that embracing a free market system is the only way out. As a result, Korea's trade liberalization has even sped up since 1997 through signing a number of free trade agreements. The key factor for widening the market opening is the growing importance of trading arrangements in world trade. As an export-oriented economy, the need for strengthening political and economic ties with major trading partners is crucial. By allowing more import items to enter into the Korean market with lower trade barriers, it helps Korea to secure more export and investment from abroad. ${ }^{41}$ Acceleration of market openings in other countries and other regions has pushed Korea to follow the same path as well to survive in the highly competitive world.

The first FTA for Korea was the Korea-Chile FTA, which came into effect in 2004, and was followed by the Korea-Singapore FTA, signed in 2005. Under the FTA, Korea had to reduce the overall tariff barriers and allow more items imported into Korea. According to Korea's MOFA, as of March 2012, Korea had effectuated a total of eight FTAs with 45 countries, including the United States, ASEAN, India, the EU, Peru, Chile, Singapore, and EFTA. To enter an advanced state of trading, Korea aims to contribute regional integration within East Asia through FTAs with China and Japan. The Korea-China FTA went into effect in December 2015. Under the FTA, Korea and China agreed to abolish 79 percent and 71 percent, respectively, of tariffs within 10 years. ${ }^{42}$ Nevertheless, the scope of liberalization of the Korea-China FTA is far more limited. Many products remain protected, for example, rice and automobiles. Compared to other FTA, the KoreaUS FTA removed 98.3 percent of South Korean and 99.2 percent of US tariffs, while the KoreaEU FTA eliminates 98.1 percent of South Korean and 99.6 percent of EU tariffs within 10 years. ${ }^{43}$ It shows that China and Korea have more room to lift barriers on a wider range of industries, including green technology and entertainment. The Korea-China FTA is expected to create about 54,000 jobs over the next 10 years by expanding export markets to China, particularly in the industry of cosmetics and fashion items. ${ }^{44}$

Table 3 illustrates the current status of Korea's FTAs. The China-Korea-Japan FTA is another important FTA under negotiation. As major trading partners, allowing free movement of trading goods and services would benefit the three economies. Ahn Duk-geun state that "the three nations could establish a regional cooperative network in high-tech innovation and start-ups,

\footnotetext{
${ }^{39}$ Kim Young Jun, Conclusion: Agenda for Roh Moo-Hyuns' Reformist Considerations. In Kim Young Chan, Kim Doo Jin and Kim Young eds, South Korea: Challenging Globalization and the Post-Crisis Reform. Oxford: Chandos Publishing, 2008, p.266.

${ }^{40}$ Kim Young Jun, Conclusion: Agenda for Roh Moo-Hyuns' Reformist Considerations, p.267.

${ }^{42}$ Schott J. Jeffrey and Jung Eui Jing, South Korea-China FTA falls short on reform. East Asia Forum, 29 May 29 2016, accessed September 2016, http://www.eastasiaforum.org/2016/05/29/south-korea-china-fta-falls-short-onreform/

43 Schott J. Jeffrey and Jung Eui Jing, South Korea-China FTA falls short on reform.

44 Korea Herald, Korea-China FTA to Take Effect Dec.20. Korea Herald, December 9, 2015, accessed May 302016. http://www.koreaherald.com/view.php?ud=20151209001182
} 
similar to Silicon Valley, or collaborate on sustainable development and international governance... it would open a new chapter of prosperity in Northeast Asia, anchoring the three economies at the center of the world's wealth value chain." 45 However, the unresolved historical tensions among the three countries and Japanese resistance to lowering tariffs on agricultural imports have become the major barriers for establishing the China-Korea-Japan FTA. Besides the northeast Asia region, Korea has also tried to establish more FTAs with other regional economies, such as Mexico, Indonesia, and Malaysia.

Table 3 Korea's FTA Current Status

\begin{tabular}{|c|c|c|}
\hline FTAs in effect & FTAs under negotiation & $\begin{array}{l}\text { FTAs under } \\
\text { consideration }\end{array}$ \\
\hline Korea-Chile FTA(2004*) & Korea-Mexico FTA & $\begin{array}{l}\text { Korea- } \\
\text { MERCOSUR TA }\end{array}$ \\
\hline Korea-Singapore FTA(2006*) & Korea-GCC FTA & Korea-Israel FTA \\
\hline Korea-EFTA FTA(2006*) & Korea-Indonesia FTA & $\begin{array}{l}\text { Korea-Central } \\
\text { America FTA }\end{array}$ \\
\hline Korea-ASEAN FTA(2009*) & Korea-China-Japan FTA & $\begin{array}{l}\text { Korea-Malaysia } \\
\text { FTA }\end{array}$ \\
\hline Korea-India CEPA(2010*) & $\begin{array}{l}\text { RCEP(Regional Comprehensive Economic } \\
\text { Partnership) }\end{array}$ & \\
\hline Korea-EU FTA(2011*) & Korea-Japan FTA & \\
\hline Korea-Peru FTA(2011*) & & \\
\hline Korea-U.S FTA(2012*) & & \\
\hline Korea-Turkey FTA(2013*) & & \\
\hline Korea-Australia FTA(2014*) & & \\
\hline Korea-Canada FTA(2015*) & & \\
\hline $\begin{array}{ll}\text { Korea-New } & \text { Zealand } \\
\text { FTA }\left(2015^{*}\right) & \\
\end{array}$ & & \\
\hline Korea-China FTA(2015*) & & \\
\hline Korea-Vietnam FTA(2015*) & & \\
\hline Korea-Columbia FTA(2016*) & & \\
\hline
\end{tabular}

Source: MOFA Korea and Asia Regional Integration Centre (ARIC), 2016.

*Date of entry into force

As market opening has widened under the number of FTAs, total imports of consumer goods have increased substantially in recent years. For instance, the total imports of agricultural and livestock products, which amounted to US\$10.9 billion in 2006, will reach US\$30 billion by $2026{ }^{46}$ From 2003 to 2013, the imported fruit market has soared more than 12 percent per year. ${ }^{47}$

\footnotetext{
${ }^{45}$ China-Korea-Japan FTA to Flesh Out Cooperation in Asia. Korea Herald, Jan 17, 2016, accessed May 302016 , http://www.koreaherald.com/view.php?ud=20160117000456

${ }^{46}$ Min Seung Kyu, South Korean Agriculture: Rising Above the Waves of Open Markets. East Asia Foundation, accessed Oct $16 \quad$ 2016, http://www.keaf.org/book/EAF_Policy_Debate_South_Korean_Agriculture:_Rising_Above_the_Waves_of_Open_ Markets?ckattempt $=1$

${ }^{47}$ Min Seung Kyu, South Korean Agriculture: Rising Above the Waves of Open Markets.
} 


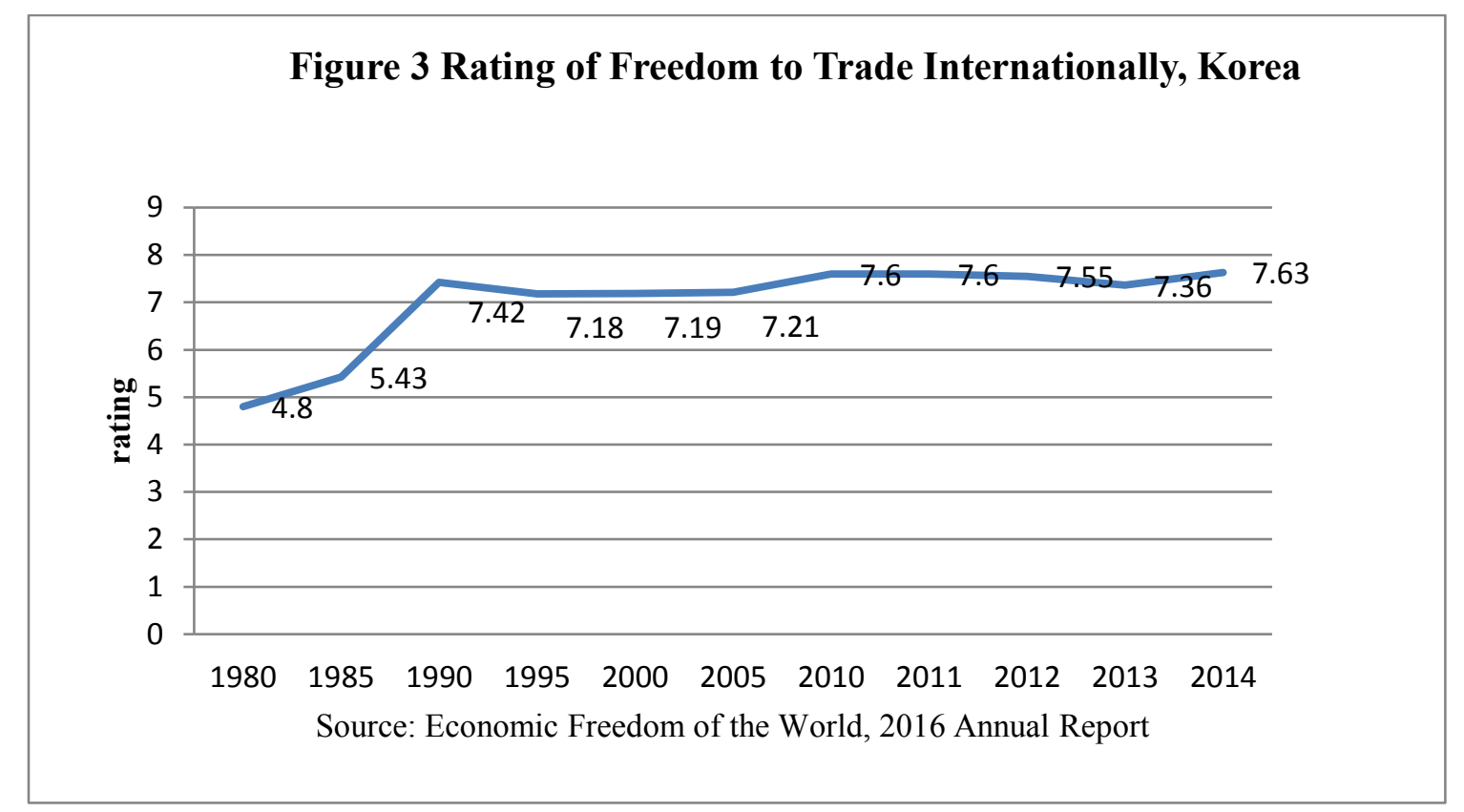

The gradual liberalization of the agricultural sector in Korea is a major improvement in Korean trade history as this sector was traditionally highly protected. Overall, Korea's trade openness has greatly improved as suggested in the Figure 3.Nonetheless, some scholars have criticized the liberalization process of foreign trade in Korea has been limited in terms of utilization rate. Many small and medium enterprises (SMEs) in Korea did not utilize FTAs and were losing interest in the FTA policy. ${ }^{48}$ For instance, the FTA utilization ratios were as low as 20 percent before $2010 .{ }^{49}$ Thus, to ensure the effectiveness of FTAs, improving the utilization rates of existing FTAs is significant in the future.

\section{Conclusion}

Historically, Korea was secluded from the outside world and gained the name of "Hermit Kingdom of the Orient." Korea closed herself off not only culturally but also economically. Korea as a collectivist society, which often stress on identity of "we" versus "other," has influenced the people's thoughts and worldviews, particularly their openness level to other groups. In the past, ethnocentrism and conservatism of Korean business firms were big obstacles for Korean firms to move forward in globalized business world, and this cultural obstacle still exists more or less. At the national level, the tendency to protect local industries as well as cultural distance have created an unfriendly business environment for foreign investors. Although the cultural openness level remains low compared to other countries, it has improved steadily since the 1990s. Neoliberalism has continued to override the national economic direction despite changes in the government. The

\footnotetext{
${ }^{48}$ Cheong In Kyo, Korea's Policy Package for Enhancing its FTA Utilization and Implications for Korea's Policy. Economic Research Institute for ASEAN and East Asia. ERIA Discussion Paper Series, 2014. Accessed August 21 2016. http://www.eria.org/ERIA-DP-2014-11.pdf .

${ }^{49}$ Cheong In Kyo, Korea's Policy Package for Enhancing its FTA Utilization and Implications for Korea's Policy.
} 
role and intervention of government in the market has declined to minimize the links between the government and industries. The conventional development model that had helped Korea to succeed during the 1960s and 1970s is no longer suitable for the current competitive globalized world. Greater trade openness and removal of all barriers to the cross-border flow of capital, goods, and services will enhance the growth of the economy.

Whereas Korea has been doing well in liberalizing its trade, openness toward FDI should be further enhanced for greater economic growth and job creation. The contribution of FDI inflow to Korea's GDP has been lower than 6 percent in recent years; this is quite low compared to the worldwide average of 13.7 percent; for developed countries, 20 percent; for developing countries, 17 percent; and for China, 27.6 percent. As FDI has great positive impact on employment and exports, adoption of an effective FDI policy and creation of a business-friendly environment for foreigners will be crucial for the Korean economy in the future. 